\title{
STAVOVI UČENIKA O IMPLEMENTACIJI KURIKULUMA INFORMATIČKIH PREDMETA U SREDNJE ŠKOLE
}

\author{
Tomislav Jakopec \\ Filozofski fakultet Osijek, Sveučilište u Osijeku, Republika Hrvatska \\ Ivica Zelić \\ GAUDEAMUS, prva privatna srednja škola u Osijeku s pravom javnosti, Republika Hrvatska \\ Dragan Šupe \\ Elektrotehnička škola Split, Republika Hrvatska
}

\begin{abstract}
Sažetak
U sklopu projekta ICT Znanstveni laboratorij provedeno je istraživanje s ciljem ispitivanja stavova učenika o implementiranju kurikuluma informatičkih predmeta u srednje škole. $U$ istraživanju su sudjelovala 142 učenika privatnih srednjih škola "Gaudeamus“ i „Pitagora“, od čega 72 učenice i 70 učenika koji su ispunili anketu od 13 pitanja. Analizom rezultata utvrđeno je s jedne strane da u dvjema školama ukupno 78,00 \% učenika pohađa nastavu informatike u školi i u velikom se postotku slažu s tvrdnjom da im je informatička pismenost važna za buduće zanimanje, dok s druge strane među njima 53,00 \% učenika nije upoznato s kraticom IKT (informacijsko-komunikacijska tehnologija). Učenici se uglavnom slažu s tvrdnjom da im postojeća nastava informatike nije dovoljna za nastavak obrazovanja. Takvi rezultati navode na zaključak da je potrebno obogatiti sadržaje iz nastavnog predmeta informatika, a za što postoji velik interes među samim učenicima.
\end{abstract}

Ključne riječi: informatički predmeti, kurikulum, stavovi roditelja, stavovi učenika, srednja škola

\section{UvoD}

Ubrzan razvoj informacijske tehnologije dovodi do značajnog pada cijena uređaja i opreme što omogućuje njezin ulazak u sva područja ljudskog života, a samim time i u obrazovanje. Sotiriou, Riviou, Cherouvis, Chelioti, Bogner i Franz (2016), kao i Mukama (2009) prije njih, govore kako je lakše razviti znanje u okolini koja sadrži informacijsko-komunikacijsku tehnologiju. Markoš (2014) zaključuje kako nije nužno samo uvesti tehnologiju u učionice, već i prilagoditi kurikulum te ga dodatno usmjeriti na razvoj tehnoloških kompetencija učenika i profesora. Potvrdu tih navoda u svojim radovima o iskustvima Cipra, Ujedinjenog Kraljevstva i Australije daju Fluck, Webb, Cox, Angeli, Malyn-Smith, Voogt i Zagami (2016). Navedena skupina autora govori o važnosti razvoja kurikuluma u području programiranja i kodiranja koje se u tim zemljama počinje učiti 1987., 2009. i 2015. godine. Haq (2006) napominje kako su, bez obzira na prednosti koje donosi uvođenje informatičkog kurikuluma u srednje škole, mišljenja učenika podijeljena ovisno o prethodnim znanjima i kompetencijama stečenim izvan škole. Autori Záhorec, Hašková i Munk (2012) ukazuju na nedovoljnu angažiranost učenika i profesora na primjeru Češke, Slovačke i Belgije. Potvrdu teze da sámo uvođenje informatičkih kurikuluma nije dovoljno te da profesori zbog kvalitetnijeg prenošenja znanja trebaju biti bolje educirani u svojim radovima donose Diepen, Perrenet i Zwaneveld (2011), Oyaid (2009) i Glogger (2013). Saeli, Perrenet, Jochems i Zwaneveld (2012) navode kako upravo razina znanja profesora može predstavljati problem prilikom provedbe kurikuluma te kako profesori imaju male ili osrednje spo- 
sobnosti programiranja. S druge strane, kada je riječ o učenicima srednjih škola, Papastergiou (2008), Hubwieser, Armoni, Brinda, Dagiene, Diethelm, Giannakos, Knobelsdorf, Magenheim, Mittermeir i Schubert (2011) te Baytak, Tarman i Ayas (2011) navode kako postoje različitosti u informatičkom obrazovanju diljem svijeta, odnosno kako učenici drukčije percipiraju tehnologiju, a njihova istraživanja pokazuju da su dječaci skloniji ostvarivanju karijere u polju informatike te da imaju pozitivnije mišljenje o takvoj profesiji.

Preduvjet kvalitetnijem provođenju informatičkih kurikuluma u srednjoj školi jest i kvalitetna izobrazba tijekom osnovne škole. Tolboom i Grgurina (2008) te Syslo i Kwiatkowska (2008) iznose rezultate istraživanja provedenih u Nizozemskoj i Poljskoj, gdje kažu kako se od učenika već u nižim razredima srednje škole očekuje računalna pismenost te kako je metodologija korištenja informacijskih znanosti radi rješavanja problema dobra motivacija za buduće odluke učenika o tome hoće li se u budućnosti baviti informacijsko-komunikacijskim tehnologijama. Provođenje kurikuluma treba pratiti kvalitetan sadržaj. Problematiku nedostatka relevantnih udžbenika u svome radu navode Záhorec, Hašková i Munk (2014). Promatrano u kontekstu samih područja primjene informatike ona se prema Bakoev (2010) tradicionalno povezuje s matematikom, a Edwards i O'Connor (2011) te Tomičić, Cvrtila i Pavetić (2012) smatraju kako je jednaka važnost informatičke kompetentnosti u obrazovanju učenika u medicinskim i ekonomskim predmetima.

Uvođenje informatičkog kurikuluma u srednje škole moguće je promatrati i iz kreativne i maštovite perspektive. Informacijsko-komunikacijska tehnologija potiče kreativnost među učenicima, primjerice izrađivanjem interaktivnih igara u svrhu edukacije. Upravo na toj pretpostavci svoje radove temelje Zuliani, Matić i Keteleš (2015), Munneke-de Vries (2008) te Ernest i Clark (2012). Papastergiou (2009) navodi kako učenici koji igraju računalne igrice imaju veće znanje o računalnim konceptima te su motiviraniji od onih koji ne igraju računalne igrice. Katai, Toth, Adorjani i Alpar (2014) navode kako je učenje uspješnije ako koristimo više osjetila, a korištenje informacijske tehnologije tu ima značajnu ulogu. Radosav i Marušić (2010) s pravom postavljaju pitanje mogućnosti uvođenja nastave na daljinu. Delić (2008) i Glass (2009) navode kako je nesporno da informacijsko-komunikacijska tehnologija pruža dobru osnovu za djelotvornu i kreativnu uporabu znanja te postaje nezaobilazan segment u razvoju društva, a njezino implementiranje u školski kurikulum olakšava ostvarivanje ljudskih vizija bolje budućnosti.

S obzirom na prethodna znanstvena dostignuća i praksu u drugim zemljama pretpostavka je kako će se do vrlo sličnih zaključaka doći i u slučaju projekta ICT Znanstveni laboratorij, u sklopu kojeg je provedeno ovo istraživanje. Cilj i svrhu istraživanja predstavlja ispitivanje stavova učenika prema implementiranju kurikuluma informatičkih predmeta u srednje škole. U odnosu na prethodne radove specifičnost ovog istraživanja čini kontekst privatnih srednjih škola. Kako u trenutku provođenja istraživanja ispitanici nisu bili upoznati s ishodima projekta u vidu informatičkih kurikuluma, valja navesti krajnje rezultate i nazive kreiranih kurikuluma:

1. Statično oblikovanje sadržaja

2. Dinamično oblikovanje sadržaja na mreži

3. Baze podataka

4. Izrada sadržaja podržana programiranjem.

\section{Metoda}

\section{Sudionici}

$\mathrm{U}$ istraživanju su sudjelovala 142 ispitanika, odnosno učenika privatnih srednjih škola "Gaudeamus" (nastavnog programa opće gimnazije) i „Pitagora“ (nastavnog programa jezične gimnazije). 
Tomislav Jakopec, Ivica Zelić, Dragan Šupe STAVOVI UČENIKA O IMPLEMENTACIII KURIKULUMA

\section{Instrument}

Istraživanje je provedeno kvantitativnom metodom anketnog upitnika. Dio anketnog upitnika sastavljen je prema Likertovoj skali od 1 do 5 , čije vrijednosti predstavljaju odluke na postavljena pitanja u rasponu od "sigurno ne" do "sigurno da“, a stupnjevi slaganja s predstavljenim tvrdnjama kreću se u rasponu od "uopće se ne slažem" do „u potpunosti se slažem". Podaci su obrađeni statističkim paketom SPSS. Značajne razlike u rezultatima ustanovljene su t-testom, hi-kvadrat-testom i analizom varijance.

\section{Postupak}

Istraživanje je provedeno tijekom prosinca 2015. godine ispunjavanjem anketnog upitnika za učenike koji se sastojao od 13 pitanja koja možemo kategorizirati u pet skupina:

1. demografski podaci

2. podaci o ocjenama

3. podaci o preferencijama prema skupinama predmeta

4. podaci o poznavanju terminologije projekta

5. podaci o korištenju ishoda projekta.

Učenici su ispunjavali upitnik pitanje po pitanje uz nadzor nastavnika kako bi anketa bila u cijelosti provedena, a trajalo je manje od 20 minuta.

\section{REZULTATI}

Unutar ukupnog broja ispitanika, ženska i muška populacija bile su gotovo jednako zastupljene, pa je anketu ispunilo 50,80 \% učenica i 49,20 \% učenika.

Rezultati pokazuju da je među ispitanicima 57,60 \% polaznika srednje škole „Gaudeamus" te $42,40 \%$ polaznika srednje škole „Pitagora“.

Unutar ukupnog broja ispitanika najveći dio činili su učenici prvog razreda srednje škole $(29,00 \%)$, zatim učenici drugog $(26,70 \%)$ i četvrtog razreda $(23,70 \%)$, dok je anketi pristupilo najmanje učenika trećeg razreda $(20,60 \%)$, kao što je prikazano na Grafikonu 1.

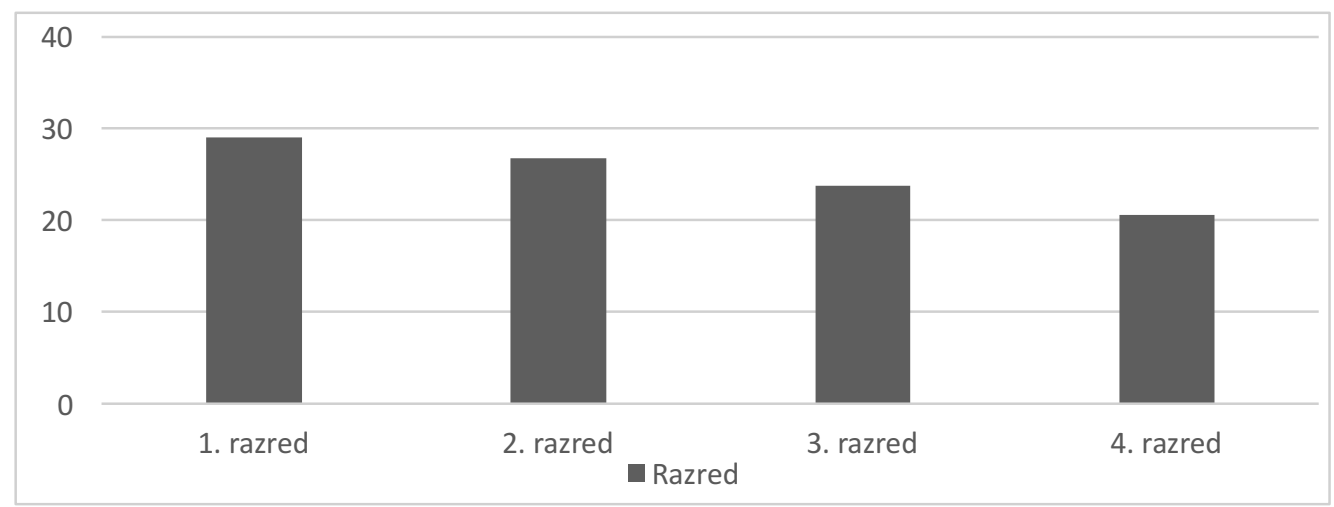

Grafikon 1. Distribucija učenika po razredima

U prethodnoj školskoj godini (2013./2014.) opći prosjek ocjena svih razrednih godina i iz svih nastavnih predmeta bio je 4,02 $(S D=0,70)$. Slika 4. prikazuje ispitani prosjek ocjena za 
prethodnu školsku godinu iz nastavnih predmeta STEM područja: Matematike, Fizike, Biologije, Kemije i Informatike. Pritom je najveći prosjek ocjena $(M=4,61, S D=0,71)$ postignut iz Informatike, a slijede ga Biologija $(M=4,05, S D=0,93)$, Kemija $(M=3,73, S D=1,16)$, Fizika $(M=3,69$, $\mathrm{SD}=1,07)$ te na posljednjem mjestu Matematika s najmanjim ostvarenim prosjekom ocjena od $3,20(S D=1,17)$, a što ukupno čini prosjek od $3,89(S D=0,76)$ za sve nastavne predmete iz STEM područja. S obzirom na to da je informatika izborni predmet, važno je naglasiti kako $77,70 \%$ ispitanika pohađa informatiku u sklopu nastavnog programa u svojoj školi.

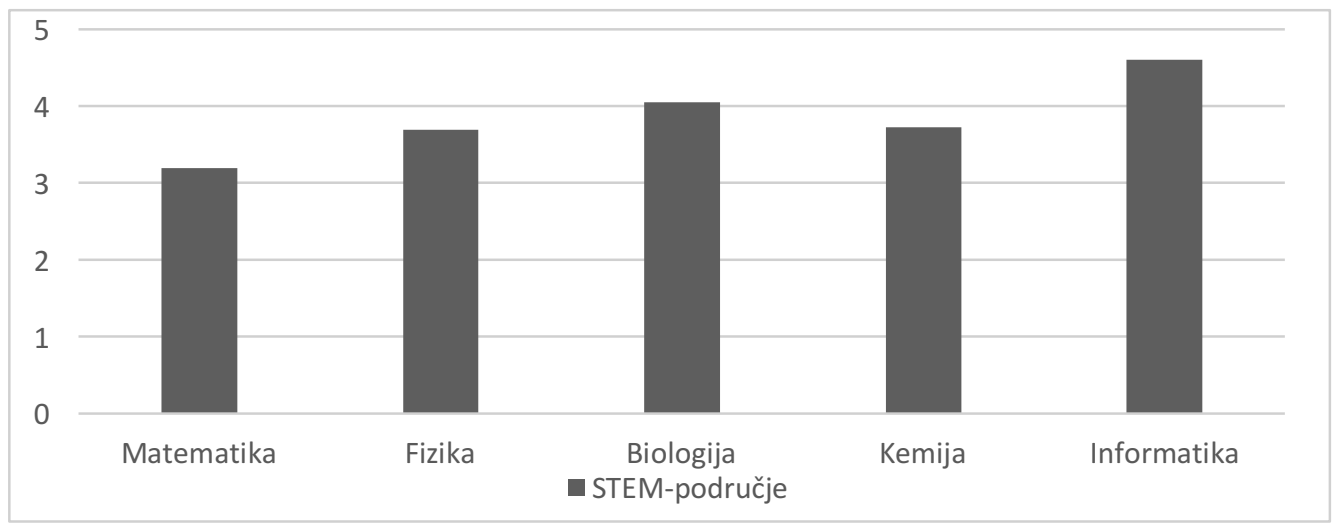

Grafikon 2. Prosjek ocjena u predmetima iz STEM područja

Anketom su ispitani i stavovi učenika o pojedinim nastavnim predmetima iz programa za jezične i opće gimnazije, a koji su podijeljeni na prirodne (Matematika, Fizika, Biologija, Kemija...) i društvene predmete (Hrvatski jezik, Sociologija, Psihologija, Filozofija...). Na Slici 5. prikazani su odgovori u kojima $46,60 \%$ ispitanika tvrdi kako su im općenito draži društveni predmeti, 31,30 \% odgovara kako su im draži prirodni predmeti, dok 22,10 \% nije sigurno za koju se skupinu opredijeliti.

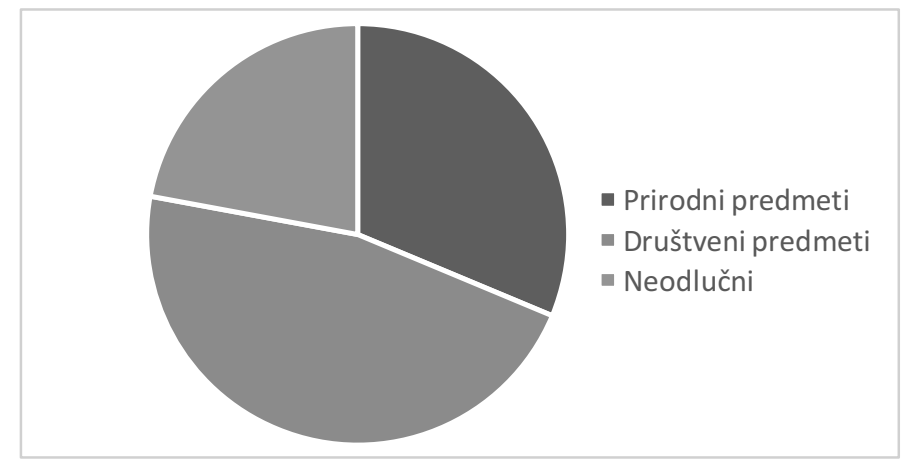

Grafikon 3. Preferencije učenika prema skupinama predmeta

Grafikon 4. prikazuje distribuciju rezultata učeničkog odabira triju najdražih predmeta, dok su u nastavku teksta opisani svi prikupljeni podaci. Kao prvi najdraži predmet učenici najčešće odabiru Povijest (16,60 \%), Engleski jezik (12,88 \%), Biologiju $(10,61 \%)$ i Informatiku $(9,09 \%)$, zatim Fiziku i Matematiku s jednakim rezultatom (6,82 \%), Hrvatski jezik te Tjelesnu i 
Tomislav Jakopec, Ivica Zelić, Dragan Šupe STAVOVI UČENIKA O IMPLEMENTACIJI KURIKULUMA

zdravstvenu kulturu (6,06 \%), Psihologiju (5,30\%), Kemiju i Njemački jezik (4,55 \%), Geografiju, Likovnu umjetnost i Talijanski jezik (2,77 \%) te Politiku i gospodarstvo i Vjeronauk (1,52 \%), a na posljednjem je mjestu Glazbena umjetnost (0,76 \%). Kao drugi najdraži predmet većina ispitanika (16,67 \%) odabire Biologiju, slijede Engleski jezik, Informatika i Povijest $(9,09 \%)$, Fizika (8,33\%), Geografija te Tjelesna i zdravstvena kultura (7,58 \%), Matematika (6,06 \%), Kemija i Likovna umjetnost (4,55 \%), Hrvatski jezik, Sociologija i Vjeronauk (3,03 \%), Etika i Talijanski jezik $(2,27 \%)$ te Psihologija (1,52 \%), dok najmanji postotak $(0,76 \%)$ imaju Latinski jezik, Njemački jezik i Politika i gospodarstvo. Kao treći najdraži predmet najveći dio učenika $(12,88$ $\%)$ odabire Biologiju, a slijede ju Matematika (9,85\%), Informatika i Povijest (8,33 \%), Tjelesna i zdravstvena kultura (7,58 \%), Engleski jezik (6,82 \%), Geografija (6,06 \%), Hrvatski jezik, Njemački jezik i Sociologija (5,30 \%), Kemija (3,79\%), Fizika (3,03 \%), Likovna umjetnost, Španjolski jezik i Politika i gospodarstvo (2,27 \%), Filozofija, Glazbena kultura i Psihologija (1,52 \%) te Etika, Latinski jezik, Logika, Talijanski jezik i Vjeronauk $(0,76 \%)$. Vidljivo je kako nastavni predmet Biologija pokazuje najveću frekventnost u odabiru ispitanika, odnosno $40,15 \%$ ispitanika svrstava ju među prva tri najdraža predmeta, a zatim slijede Povijest $(34,09 \%)$, Engleski jezik $(34,09 \%)$, Informatika (26,52 \%), Matematika (22,73\%), Tjelesna i zdravstvena kultura $(21,21$ $\%)$, Fizika (18,18 \%), Geografija (15,91 \%), Hrvatski jezik (14,39 \%), Kemija (12,88 \%) i Njemački jezik $(10,61 \%)$, dok ispod $10 \%$ ostaju sljedeći nastavni predmeti: Likovna umjetnost (9,09 \%), Psihologija (8,33 \%), Sociologija (8,33 \%), Talijanski jezik (5,30\%), Vjeronauk (5,30 \%), Politika i gospodarstvo (4,55 \%), Etika (3,03\%), Španjolski jezik (2,27\%), Glazbena umjetnost (2,27 \%), Filozofija (1,52 \%), Latinski jezik (1,52 \%) i Logika (0,76 \%).

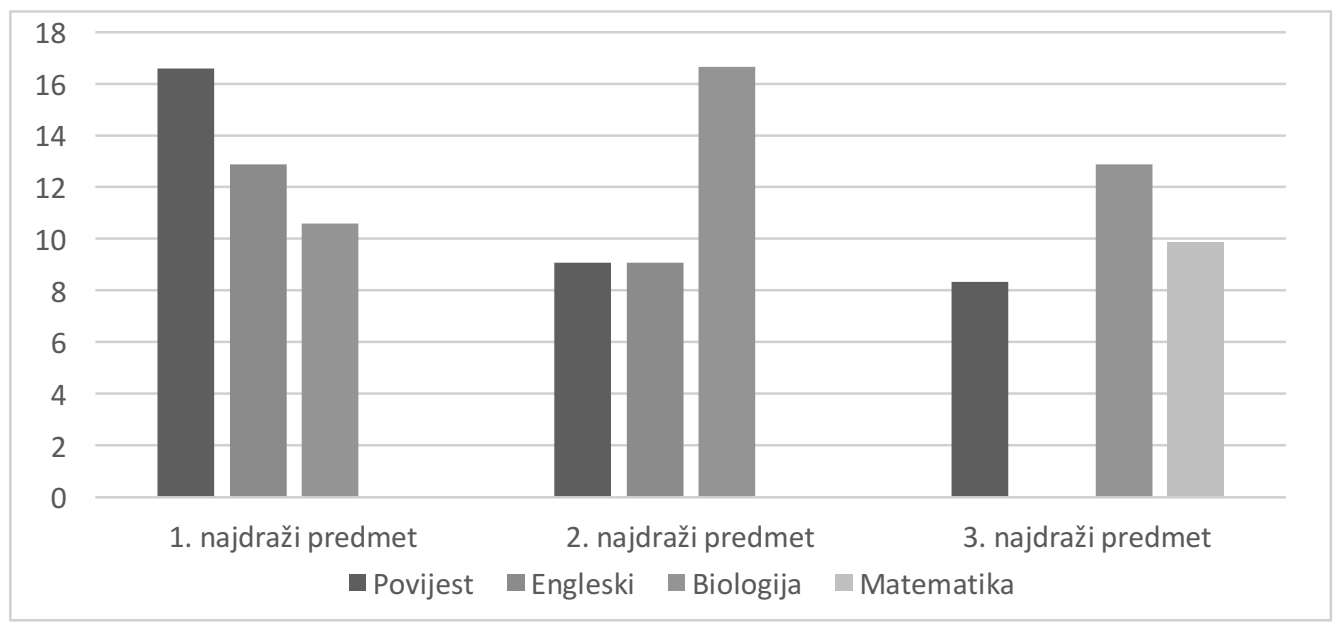

Grafikon 4. Distribucija prvih triju rezultata u odabiru učenika

U ukupnim rezultatima učenici nastavne predmete iz STEM područja odabiru kao prva tri najdraža predmeta. Biologija, Informatika i Matematika zastupljeni su s više od $20,00 \%$, a Fizika i Kemija nalaze se s nešto manjim frekvencijama. Stavovi o najdražim predmetima (među prva tri) djelomično se podudaraju s općenitim stavovima učenika o tome jesu li im draži predmeti iz polja društvenih ili prirodnih znanosti. Odgovarajući na prethodna pitanja o ocjenama iz pojedinih predmeta i preferencijama, učenici nisu bili upoznati s pojmom STEM područja. Stoga Grafikon 5. prikazuje upoznatost učenika s općenitim definicijama područja STEM-a i IKTa. Tako se svega 3,00 \% učenika susrelo s kraticom STEM i točno zna što ona označava; $12,90 \%$ ispitanika susrelo se $s$ kraticom, ali samo otprilike zna što ona označava; $14,40 \%$ susrelo se $s$ kraticom, ali ne zna što ona označava, a 69,70 \% nije se susrelo s kraticom i ne zna što ona 
označava. Sličan trend uočljiv je i u rezultatima ispitivanja značenja kratice IKT, gdje se nešto veći dio od 6,10 \% susreo s navedenom kraticom i točno zna što označava; $24,20 \%$ učenika susrelo se s kraticom, ali samo otprilike zna što ona označava; $16,70 \%$ susrelo se $s$ kraticom, ali ne zna što ona označava, a 53,00 \% nije se susrelo s kraticom i ne zna što ona označava. Na temelju navedenih rezultata može se zaključiti kako je područje STEM-a i IKT-a učenicima još uvijek velika nepoznanica te oni u visokim postocima - čak 69,70 \% za STEM i 53,00 \% za IKT ne znaju što kratice označavaju niti su se susreli s navedenim područjem.

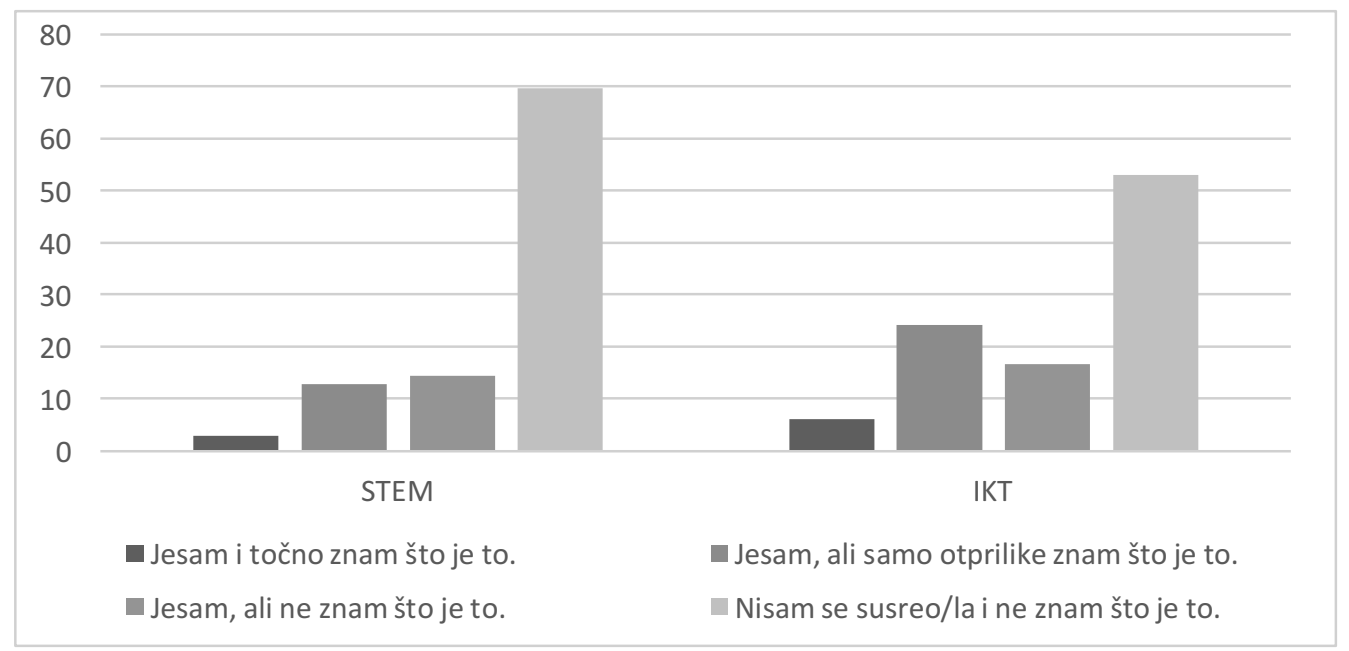

Grafikon 5. Poznavanje općenitih definicija od strane učenika

Učenicima je u anketnom upitniku ponuđena mogućnost odabira područja novih fakultativnih predmeta koji bi, među ostalim, omogućavali izradu mrežnih i mobilnih aplikacija te izradu aplikacija zaWindows i Java programiranje. Pritom je velik dio od 33,30\%, odnosno $20,60 \%$ odgovora u kojima učenici tvrde da bi sigurno upisali predmete koji bi nudili sadržaje izrade mobilnih i Windows aplikacija, dok manji dio čine afirmativni odgovori („,sigurno da“) za sadržaje poput izrade mrežnih aplikacija $(12,40$ \% odgovora) i Java programiranja $(16,80 \%$ odgovora). Rezultati su prikazani na Grafikonu 6.

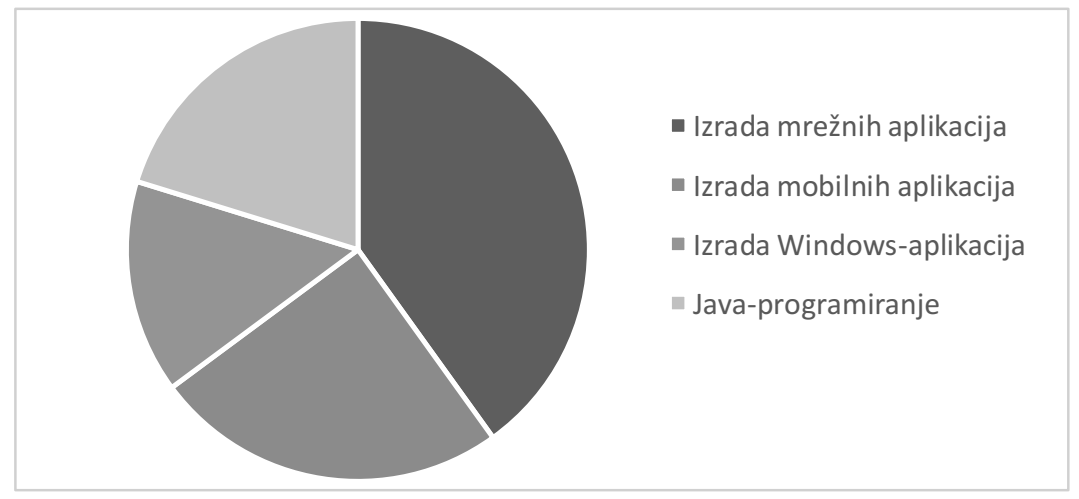

Grafikon 6. Preferencije učenika prema područjima novih fakultativnih predmeta 
Tomislav Jakopec, Ivica Zelić, Dragan Šupe STAVOVI UČENIKA O IMPLEMENTACIJI KURIKULUMA

Na kraju anketnog upitnika, učenici su iskazali stavove o informatici te o informacijskoj i komunikacijskoj tehnologiji. Slika 9. prikazuje rezultate koji pokazuju kako se većina učenika slaže ili se u potpunosti slaže da je informatička pismenost vrlo važna za njihovo buduće zanimanje, no zabrinjava činjenica da je velik udio ispitanika ipak neodlučan po tom pitanju ili se, pak, uopće ne slažu s tvrdnjom da su navedene vještine iz IKT-a važne za njihov budući posao $(M=3,71, S D=1,05)$. S nešto većom srednjom vrijednosti $(M=4,15, S D=0,85)$ većina se slaže ili se u potpunosti slaže kako bi im općenita informatička znanja mogla pomoći u budućem traženju zaposlenja kao i da bi im znanje iz programiranja mrežnih i mobilnih aplikacija moglo pomoći u budućem traženju zaposlenja $(M=3,35, S D=1,20)$. U anketi je ispitan i općeniti stav učenika o nastavnom predmetu Informatika koji se provodi unutar njihovih nastavnih programa. Tako srednja vrijednost od 3,54 (SD=1,03) odgovora pokazuje kako se učenici uglavnom slažu (33,3 \% odgovora) da im informatička znanja mogu pomoći u svladavanju školskog gradiva čak i kod predmeta koji nisu povezani s informatikom, no isto tako velik postotak odgovora $(32,6 \%)$ sugerira kako se učenici niti slažu niti se ne slažu s navedenom tvrdnjom. Nešto niži postotak odgovora sa srednjom vrijednosti od $3,16(S D=1,17)$ sugerira kako učenici smatraju da postojeća nastava informatike nije dovoljna s obzirom na znanja koja će im po završetku školovanja trebati. Njih $28,5 \%$ u potpunosti se slaže da bi informatika trebala biti obvezan predmet u svim razredima srednjih škola, a većina odgovora (32 \%) također sugerira kako učenici smatraju da informatika ne bi trebala biti obvezna samo u nekim strukovnim školama. Općenito, veći postotak odabira afirmativnih odgovora („slažem se“ ili „u potpunosti se slažem“) utvrđen je u stavovima učenika koji smatraju da se gradivo koje uče na satima informatike ponavlja u odnosu na gradivo iz osnovne škole, da bi postojeće gradivo iz informatike trebalo osuvremeniti te da bi nastava iz informatike trebala obuhvaćati više programiranja, a ne uglavnom samo osnovno korištenje računala.

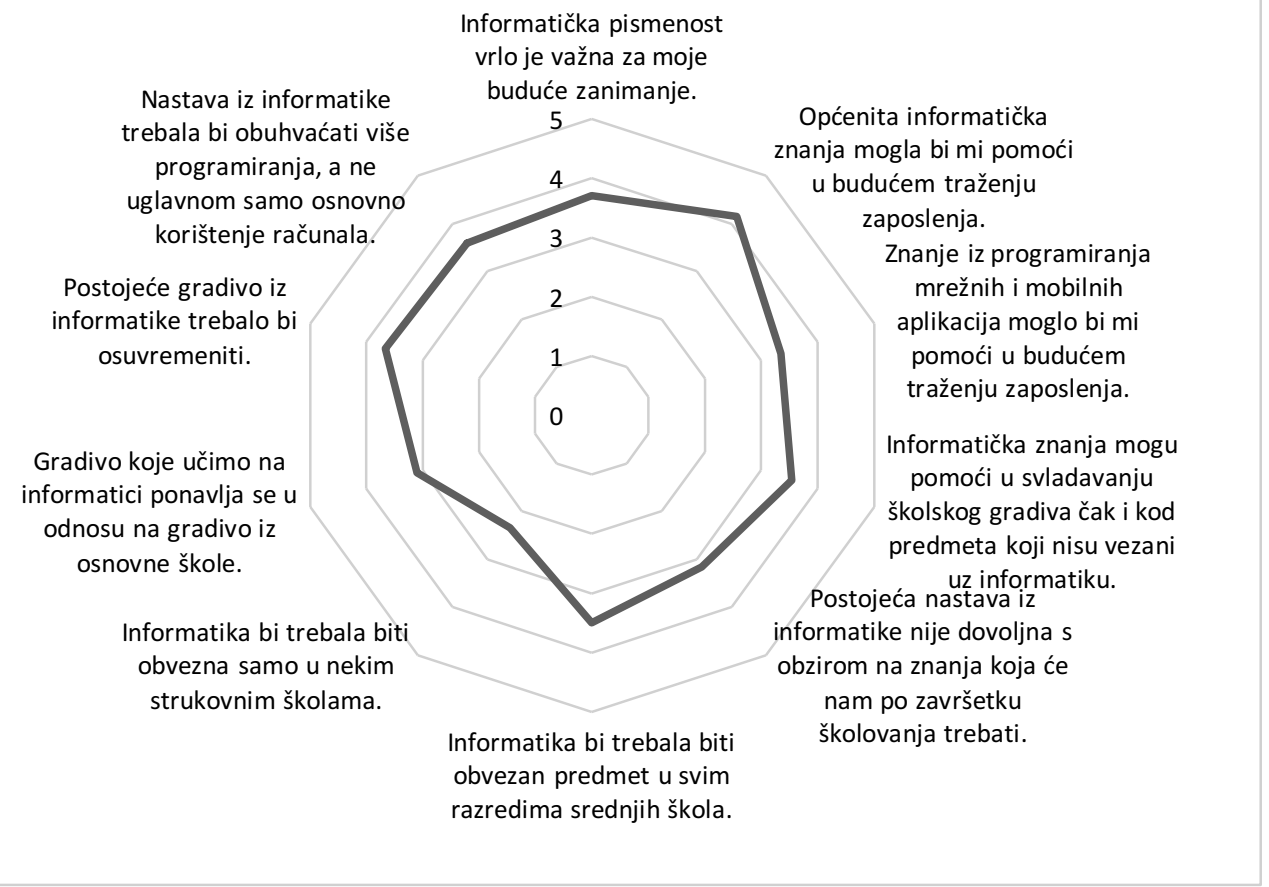

Shema 1. Stavovi o informatici iinformacijsko-komunikacijskoj tehnologiji 
Analizom usporedbe rezultata prema nezavisnim varijablama spola, prosjeka ocjena $\mathrm{i}$ škole, za prosječne ocjene učenici su svrstani u skupine prema „okruglim“ ocjenama (npr. oni koji su prošli s dobrim, vrlo dobrim ili izvrsnim). Učenika s prosječnom ocjenom „dovoljan“ bilo je samo tri, pa su oni izostavljeni iz analize. Prosjek ocjena u prošloj školskoj godini statistički je značajno veći kod učenica nego kod učenika, i to prema rezultatima u Tablici 1., dok je prosjek ocjena prikazan u Tablici 2. veći u srednjoj školi „Gaudeamus“.

Tablica 1. Prosjek ocjena u prošloj školskoj godini po spolu

\begin{tabular}{|l|c|c|c|c|c|c|}
\hline & $\mathrm{M}(\mathrm{SD})$ & $\check{\mathrm{Z}}$ & $\mathrm{M}$ & $\mathrm{t}^{*}$ & $\mathrm{df}$ & $\mathrm{p}$ \\
\hline Opći prosjek & $4,02(0,70)$ & $4,32(0,56)$ & $3,70(0,69)$ & 5,439 & 121 & $<0,001$ \\
\hline Matematika & $3,20(1,17)$ & $3,52(1,16)$ & $2,85(1,06)$ & 3,444 & 126 & 0,001 \\
\hline Fizika & $3,69(1,07)$ & $3,98(1,02)$ & $3,38(1,03)$ & 3,279 & 125 & 0,001 \\
\hline Biologija & $4,05(0,93)$ & $4,44(0,77)$ & $3,65(0,93)$ & 5,247 & 126 & $<0,001$ \\
\hline Kemija & $3,73(1,16)$ & $3,97(1,04)$ & $3,46(1,23)$ & 2,512 & 119 & 0,013 \\
\hline
\end{tabular}

* $\mathrm{t}$ - test nezavisnih uzoraka

Tablica 2. Prosjek ocjena u prošloj školskoj godini po školi

\begin{tabular}{|l|c|c|c|c|c|c|}
\hline & $\mathrm{M}(\mathrm{SD})$ & Gaudeamus & Pitagora & $\mathrm{t}^{*}$ & $\mathrm{df}$ & $\mathrm{p}$ \\
\hline Opći prosjek & $4,02(0,70)$ & $4,19(0,66)$ & $3,80(0,69)$ & 3,155 & 122 & 0,002 \\
\hline Kemija & $3,73(1,16)$ & $4,26(0,93)$ & $3,04(1,06)$ & 6,818 & 128 & $<0,001$ \\
\hline Informatika & $4,61(0,71)$ & $4,84(0,40)$ & $4,21(0,93)$ & 4,000 & 45 & $<0,001$ \\
\hline
\end{tabular}

* $\mathrm{t}$ - test nezavisnih uzoraka

U odgovorima na pitanje jesu li se dosad susreli s pojmom STEM postoji značajna razlika između škola $\left(\chi^{2}(3, N=132)=8,547, p=0,036\right)$. Učenici prema Tablici 3. najčešće daju odgovore kako se nisu susreli s pojmom te kako ne znaju što on predstavlja.

Tablica 3. Poznavanje pojma STEM

\begin{tabular}{|l|c|c|c|c|}
\hline & Frekvencija & \% odgovora & Gaudeamus & Pitagora \\
\hline Jesam i točno znam što je to. & 4 & 3,0 & 2,6 & 3,6 \\
\hline Jesam, ali samo otprilike znam što je to. & 17 & 12,9 & 18,4 & 5,4 \\
\hline Jesam, ali ne znam što je to. & 19 & 14,4 & 18,4 & 8,9 \\
\hline Nisam se susreo/la i ne znam što je to. & 92 & 69,7 & 60,5 & 82,1 \\
\hline
\end{tabular}

Učenici srednje škole "Gaudeamus“ ipak su se više susretali s pojmom IKT (ICT), što je i vidljivo u tablici $4\left(\chi^{2}(3, N=132)=22,182, p<0,001\right)$. 
Tomislav Jakopec, Ivica Zelić, Dragan Šupe STAVOVI UČENIKA O IMPLEMENTACIJI KURIKULUMA...

Tablica 4. Poznavanje pojma IKT (ICT)

\begin{tabular}{|l|c|c|c|c|}
\hline & Frekvencija & \% odgovora & Gaudeamus & Pitagora \\
\hline Jesam i točno znam što je to. & 8 & 6,1 & 7,9 & 3,6 \\
\hline Jesam, ali samo otprilike znam što je to. & 32 & 24,2 & 34,2 & 10,7 \\
\hline Jesam, ali ne znam što je to. & 22 & 16,7 & 22,4 & 8,9 \\
\hline Nisam se susreo/la i ne znam što je to. & 70 & 53,0 & 35,5 & 76,8 \\
\hline
\end{tabular}

Broj učenika koji ne žele upisati fakultet vrlo je malen, pa je u interpretaciji Tablica 5., 6. i 7. napravljena usporedba onih koji žele na fakultet u odnosu na sve ostale. Odgovori „ne“ i „ne znam“ spojeni su u zajedničku kategoriju zbog činjenice da je broj učenika koji ne žele upisati fakultet mali, no mnogi zapravo ne znaju koji bi fakultet upisali. Prema spolu fakultet želi upisati više učenica, dok to ne želi ili ne zna više učenika $\left(\chi^{2}(1, N=128)=3,953, p=0,047\right)$. S obzirom na školu fakultet želi upisati više polaznika "Gaudeamusa“, dok u „Pitagori“ ipak ima više neodlučnih $\left(\chi^{2}(1, N=130)=6,687, p=0,010\right)$. Prema prosjeku ocjena učenici $s$ boljim ocjenama imaju veću namjeru upisati fakultet $\left(\chi^{2}(2, N=119)=8,837, p=0,012\right)$.

Tablica 5. Namjera upisivanja fakulteta prema spolu

\begin{tabular}{|l|c|c|c|c|}
\hline & Frekvencija & \% odgovora & 乙̌ & M \\
\hline "Da.“ & 115 & 88,5 & 93,8 & 82,5 \\
\hline "Ne.“ "ili „Ne znam još.“ & 15 & 11,5 & 6,2 & 17,5 \\
\hline
\end{tabular}

Tablica 6. Namjera upisivanja fakulteta s obzirom na školu

\begin{tabular}{|l|c|c|c|c|}
\hline & Frekvencija & \% odgovora & Gaudeamus & Pitagora \\
\hline „Da.“ & 115 & 88,5 & 94,7 & 80,0 \\
\hline "Ne.“ ili „Ne znam još.“ & 15 & 1,5 & 5,3 & 20,0 \\
\hline
\end{tabular}

Tablica 7. Namjera upisivanja fakulteta prema prosjeku ocjena

\begin{tabular}{|l|c|c|c|c|c|}
\hline & Frekvencija & \% odgovora & dobar & v. dobar & izvrstan \\
\hline "Da.“ & 115 & 88,5 & 77,3 & 87,5 & 100,0 \\
\hline „Ne.“ ili „Ne znam još.“ & 15 & 11,5 & 22,7 & 12,5 & 0,0 \\
\hline
\end{tabular}

Među učenicima prema spolu, prosjeku, ocjeni i školi općenito nema razlike u stavovima.

\section{ZAKUUČAK}

Prema navedenim rezultatima može se zaključiti kako je većina učenika zainteresirana za uvođenje novih nastavih sadržaja u sklopu nastavnog predmeta Informatika s ciljem svladavanja novih znanja o izradi mobilnih i mrežnih aplikacija. Rezultate treba promatrati u granicama jedne školske godine u dvjema privatnim gimnazijama. Upravo u tom ograničenju leži i 
drugo ograničenje - mali uzorak od 142 učenika. Kao jasan pokazatelj za polaznike nastavnih programa gimnazije, bilo jezične ili opće, u namjeri nastavka njihova obrazovanja u tercijarnom sektoru važan je rezultat prema kojem čak 88,5 \% odgovora izražava jasan stav učenika da namjeravaju nastaviti svoje obrazovanje. Vrlo mali udio od 1,5\% negativnih odgovora potkrepljuje stav o tome da ne žele nastaviti svoje obrazovanje, dok ih još 10,0 \% ne zna odgovor. Glede odabira konkretnog fakulteta, a prema frekventnosti odgovora iz rezultata ankete, najviše učenika izabralo je medicinski fakultet, a zatim ekonomski, filozofski, pravni, elektrotehnički, farmaceutski, kineziološki i pedagoški. No važno je istaknuti kako prema mjerljivim pokazateljima ankete, frekventnosti odgovora, većina učenika još uvijek ne zna koji bi fakultet upisali, a što je i očekivano s obzirom na to da su većinu ispitanika provedene ankete činili učenici razrednih odjeljenja svih razreda. Također, može se zaključiti kako se na ljestvici prihvatljivih studija za upis učenika prema njihovu izboru ipak ponajprije nalaze studiji povijesti, engleskog i biologije, nakon kojih slijede studiji informatike i fizike. Pretpostavka je kako će provođenje kurikuluma IT predmeta u idućem razdoblju izmijeniti ljestvicu poželjnih studija u korist STEM-a.

Provedeno istraživanje sastavni je dio aktivnosti u okviru projekta ICT Znanstveni laboratorij, a u sklopu poziva za dostavu projektnih prijedloga Promocija kvalitete $i$ unaprjeđenje sustava odgoja i obrazovanja na srednjoškolskoj razini, broj ugovora: HR.3.1.20 - 0017.

\section{LITERATURA}

Bakoev, V. P. (2010). The recurrence relations in teaching students of informatics. Informatics in Education 9, (2), 159-170. Preuzeto s https://files.eric.ed.gov/fulltext/EJ1064359.pdf, 22.7. 2016.

Baytak, A., Tarman, B i Ayas, C. (2016). Experiencing technology integration in education: Children's perceptions. International Electronic Journal of Elementary Education, 3(2), 139-151. Preuzeto s https://search.proquest.com/openview/7f8844c3f75eb6dde3c0ca65a4d9f923/1?pqorigsite $=$ gscholar, 23.7.2016.

Delić, N. (20018). Informaciono-komunikacione tehnologije u obrazovanju. Preuzeto s http:// apeironsrbija.edu.rs/Centar_za_izdavacku_djelatnost/Radovi/Specijalisticki/NedimDelic.pdf, (2016-07-22)

Diepen, N.M., Perrenet, J. C. i Zwaneveld, B. (2011). Which way with informatics in high schools in the Netherlands? The Dutch dilemma. Informatics in Education 10(1), 123-148. Preuzeto s

https://eric.ed.gov/?q=informatics+curriculum+in+high+school\&ft=on\&ff1=dtySince_2007\&ff2=pu bJournal+Articles\&id=EJ1064280, 22.7.2016.

Edwards, J. i O'Connor, P. A. (2011). Improving technological competency in nursing students: The passport project. Journal of Educators Online 8,(2), 1-20.

Ernest, J. V. i Clark, A. C. (2012). Fundamental computer science conceptual understandings for high school students using original computer game design. Journal of STEM education: innovations \& research, 13(5), 40-45.

Fluck, A., Webb, M., Cox, M., Angeli, C., Malyn-Smith, J., Voogt, J. i Zagami, J. (2016). Arguing for computer science in the school curriculum. Journal of educational technology \& society, 19(3), 38-46.

Glass, G. V. i Michalinos Zembylas, C. V. (2009). Technology Centre for the Advancement of Research \& Development in Educational technology. ICT for education, development and social justice. Charlotte, NC: Information Age Publishing, 2009. eBook Collection, 2016.

Preuzeto $s$ https://proxy.nsk.hr/nph-proxy.pl/en/00/http/eds.a.ebscohost.com/eds/detail/detail= $3 \mathrm{fsid}=3 \mathrm{de} 78 \mathrm{af07f}-\mathrm{bc} 84-4 \mathrm{aa} 8-\mathrm{b} 6 \mathrm{~b} 6-\mathrm{f} 255 \mathrm{fe} 3 \mathrm{e} 4 \mathrm{cc0}=2540$ sessionmgr4008 $=26 \mathrm{vid}=3 \mathrm{~d} 0=26 \mathrm{hid}=$ 3d4211=26bdata=3dJmxhbmc9aHImc2 I0ZT1IZHMtbGI2ZQ=253d=253d\#AN=469967\& db=nlebk, 22.7.2016. 
Tomislav Jakopec, Ivica Zelić, Dragan Šupe STAVOVI UČENIKA O IMPLEMENTACIJI KURIKULUMA...

Glogger, I., Holzäpfel, L., Kappich, J., Schwonke, R., Nückles, M. i Renkl, A. (2016). Development and evaluation of a computer-based learning environment for teachers: Assessment of learning strategies in learning journals. Education research international 2013, 12. Preuzeto s http:// www.hindawi.com/journals/edri/2013/785065/, 23.7.2016.

Haq, N. (2016). Pupils' views and experience of ICT in secondary schools. Preuzeto s https://proxy. nsk.hr/nph-proxy.pl/en/00/http/www.dart-europe.eu/full.php=3fid=3d338562, 23.7.2016.

Hubwieser, P., Armoni, M., Brinda, T., Dagiene, V., Diethelm, I., Giannakos, M. N., Knobelsdorf, M., Magenheim, J., Mittermeir, R. i Schubert, S. (2011). Computer science/informatics in secondary education. U: Proceedings of the 16th annual conference reports on Innovation and technology in computer science education - working group reports (str. 19-38). Preuzeto s http://dl.acm. org/citation.cfm?id=2078859, 26.7.2016.

Katai, Z., Toth, L. i Adorjani, A. K. (2014). Multi-sensory informatics education. Informatics in Education 13(2), 225-240. Preuzeto s https://eric.ed.gov/?q=student+opinion+on+ implementing+informatics+in+high+school\&ft=on\&id=EJ1064323, 22.7.2016.

Markoš, R. (2016). Integracija novih obrazovnih tehnologija u kurikulum. Diplomski rad.

Osijek: Sveučilište Josipa Jurja Strossmayera, Filozofski fakultet, Odsjek za pedagogiju. Preuzeto s https://zir.nsk.hr/islandora/object/ffos:367, 22.7.2016.

Mukama, E. (2009). Information and Communication Technology in Teacher Education: Thinking and learning in computer-supported social practice. Linköping : Linköping University Electronic Press. Preuzeto s https://proxy.nsk.hr/nph-proxy.pl/en/00/http/www.dart-europe.eu/full. php=3fid=3d167641, 26.7.2016.

Munneke-de Vries, E.L. (2016). Arguing to learn: Supporting interactive argumentation through computer-supported collaborative learning. Preuzeto $s$ https://proxy.nsk.hr/nph-proxy.pl/en/ 00/http/www.dart-europe.eu/full.php=3fid=3d545729, 22.7.2016.

Oyaid, A. A. (2016). Education policy in Saudi Arabia and its relation to secondary school teachers' ICT use, perceptions, and views of the future of ICT in education. Preuzeto s https://ore.exeter. ac.uk/repository/handle/10036/69537, 23.7.2016.

Papastergiou, M. (2008). Are computer science and information technology still masculine fields? High school students' perceptions and career choices. Computers \& Education 51(2), 594-608.

Preuzeto s http://www.sciencedirect.com/science/article/pii/S0360131507000759, 26.7.2016.

Papastergiou, M. Digital game-based learning in high school computer science education: Impact on educational effectiveness and student motivation. Computers \& Education 52(1), 1-12.

Preuzeto s http://www.sciencedirect.com/science/article/pii/S0360131508000845, 23.7.2016.

Radosav, D. i Marušić, T. (2010). Strategija interaktivnog učenja informatike u mrežnom okruženju. Pedagogijska istraživanja 7(1), 141-142. Preuzeto s http://hrcak.srce.hr/index.php?show= clanak\&id_clanak_jezik=174959, 23.7.2016.

Saeli, M., Perrenet, J., Jochems, W. M. G. i Zwaneveld, B. (2012). Programming: Teachers and pedagogical content knowledge in the Netherlands. Informatics in Education 11(1), 81-114.

Preuzeto s https://eric.ed.gov/?q=informatics+curriculum+in+high+school\&ft=on\&ff1=dtySince _ 2007\&ff2=pubJournal+Articles\&id=EJ1064292, 22.7.2016.

Sotiriou, S., Riviou, K., Cherouvis, S., Chelioti, E. i Bogner, F. X. (2016). Introducing large-scale innovation in schools. Journal of science education and technology 25(4), 541-549. Preuzeto $\mathrm{s}$ https://proxy.nsk.hr/nph-proxy.pl/en/00/http/apps.webofknowledge.com/full_record.do= $3 \mathrm{fproduct}=3 \mathrm{dWOS}=26$ search_mode $=3 \mathrm{~d}$ GeneralSearch $=26 \mathrm{qid}=3 \mathrm{~d} 1=26 \mathrm{SID}=$ $3 \mathrm{dP} 1 \mathrm{kyef1qEHxztdOib28}=26$ page $=3 \mathrm{~d} 1=26 \mathrm{doc}=3 \mathrm{~d} 2=26$ cacheurlFrom RightClick=3dno, 26.7.2016.

Syslo, M. M. i Kwiatkowska, A. B. (2008). The challenging face of informatics education in Poland. Informatics Education 5090, 1-18. Preuzeto s http://link.springer.com/chapter/10.1007/978-3540-69924-8_1\#page-1, 23.7.2016.

Tolboom, J. i Grgurina, N. (2008). The first decade of informatics in Dutch high schools. Informatics in education - an international journal 7(1), 55-74. Preuzeto s https://www.ceeol.com/search/ article-detail?id=88836, 22.7.2016. 
Tomičić, L., Cvrtila, M. i Pavetić, D. (2012). Važnost informatičke pismenosti učenika ekonomske škole. Učenje za poduzetništvo 2(2), 87-93. Preuzeto s http://hrcak.srce.hr/index.php?show= clanak\&id_clanak_jezik=192399, 22.7.2016.

Záhorec, J., Hašková, A. i Munk, M. (2014). Assessment of selected aspects of teaching programming in SK and CZ. Informatics in Education 13(1), 157-178. Preuzeto s https://eric.ed.gov/?q= student+opinion+on+implementing+informatics+in+high+school\&ft=on\&id=EJ1064320, 23.7.2016.

Záhorec, J., Hašková, A. i Munk, M. (2012). Results of a research evaluating quality of computer science education. Informatics in Education 11(2), 283-300. Preuzeto s https://eric.ed.gov/?q= informatics+curriculum+in+high+school\&ft=on\&ff1=dtySince_2007\&ff2=pubJournal+Articles\& id=EJ1064274, 23.7.2016.

Zuliani, Đ., Matić, M. i Keteleš, V. (2015). Poticanje kreativnosti u nastavi informatike. Život i škola: 61,(1) 25-35. Preuzeto s http://hrcak.srce.hr/index.php?show=clanak\&id_clanak_jezik=224149, 36.7.2016.

\title{
Attitudes of Students and Parents towards Implementation of IT Subjects' Curriculums in Secondary Schools
}

\begin{abstract}
As part of the project "ICT Znanstveni laboratorij" a research was carried out to investigate the attitudes of students towards the implementation of the curriculum of IT subjects in secondary schools. The study included 142 (72F, 70M) students of private grammar schools Gaudeamus and Pitagora, who completed the survey which consisted of 13 groups of questions. The results have shown that on the one hand $78 \%$ of students attend classes in computer science and a high percentage agrees with the statement that their computer literacy is important for future interest, while the other side as much as $53 \%$ of the students are not familiar with the acronym ICT (information and communication technology). A large percentage of students agree with the statement that their existing curriculum in computer science is not sufficient to continue their education in that field. These results suggest that students need to enrich the contents in the subject, for which there is great interest among students.
\end{abstract}

Keywords: attitudes of parents, curriculum, high school, IT courses, students' attitudes

\section{Die Einstellungen von Schülern zur Umsetzung des Lehrplans von It-Fächern in weiterführenden Schulen}

Zusammenfassung: Im Rahmen des Projekts „ICT Wissenschaftslabor" wurde eine Untersuchung zur Einstellung der Schüler zur Umsetzung des Lehrplans von Fächern im Bereich der Informationstechnologie in weiterführenden Schulen durchgeführt. Die Studie umfasste 142 Schülerinnen und Schüler (davon 72 Schülerinnen und 70 Schüler) der privaten Gymnasien Gaudeamus und Pitagora, die eine Umfrage mit 13 Fragen ausgefüllt haben. Die Ergebnisse haben gezeigt, dass auf der einen Seite 78\% der Schüler am Informatikunterricht in der Schule teilnimmt und ein hoher Prozentsatz der Aussage zustimmt, dass Informationsliteralität für ihren zukünftigen Beruf wichtig ist. Auf der anderen Seite waren sogar $53 \%$ der Schüler mit der Abkürzung IKT (Informations- und Kommunikationstechnologie) nicht vertraut. Die Schüler stimmen zum Großteil damit überein, dass der bestehende Informatikunterricht sie nicht zur Fortsetzung ihres Bildungsweges befähigt. Diese Ergebnisse legen nahe, dass die Inhalte im Informatikunterricht angereichert werden sollten, wofür bereits reges Interesse seitens der Schüler besteht.

Schlüsselwörter: Fächer im Bereich Informatik und Datenverarbeitung, Lehrplan, Schülereinstellungen, Elterneinstellungen, weiterführende Schule (Oberstufe) 